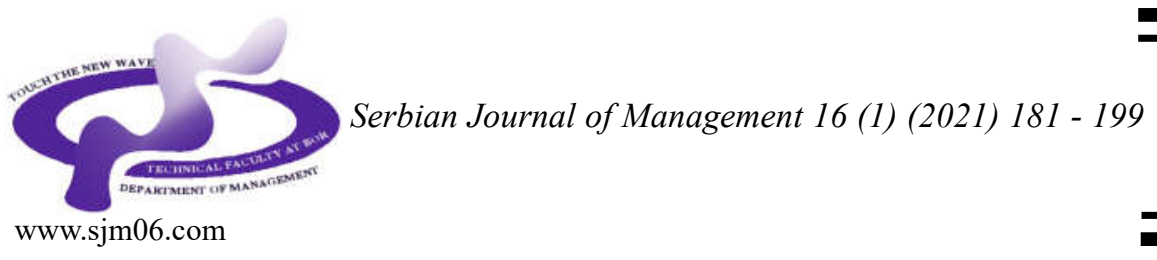

\title{
KNOWLEDGE TRANSFER FOR INNOVATIVENESS IN FAMILY BUSINESSES
}

\author{
Marina Letonja ${ }^{a^{*}}$, Mojca Duh ${ }^{b}$ and Zdenka Ženkob

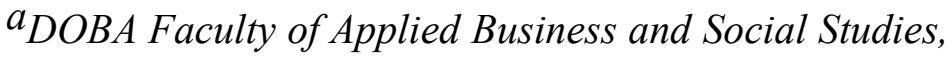 \\ Prešernova ulica 1, 2000 Maribor, Slovenia

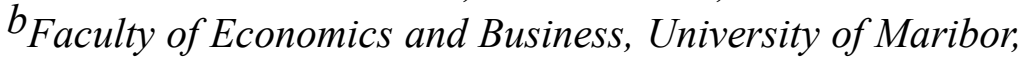 \\ Razlagova 14, 2000 Maribor, Slovenia
}

(Received 08 March 2021; accepted 24 March 2021)

\begin{abstract}
Family businesses (FB) are important in the most of national economies. We explored whether successors' innovativeness is positively associated with the transfer of the founders' innovativeness through knowledge transfer and creation processes in a form of the internal transfer of founders' tacit and experiential knowledge and skills and with the external transfer of knowledge, when potential successors attend educational programs, external training, or gain working experience in other companies. Our research reveals that when the actual forms of internal knowledge transfer are discussed, the positive correlations exist between innovativeness of successors and their early inclusion into FB, apprenticeship, inclusion of successors into meetings with business partners and strategic planning before they get involved in FB. Our survey partially confirmed that regarding external transfer of knowledge, working experiences of successors in other companies and participation in academic courses are positively associated with their innovativeness.
\end{abstract}

Keywords: family business, innovation, knowledge transfer, succession

\section{INTRODUCTION}

Family businesses (FB) are dominating and playing an important role in the most of national economies. According to some estimates the share of family businesses in
EU is more than $60 \%$ of all companies and worldwide is between 70-95\% (EFB 2017).

The transfer of FB to the next generation is often the most critical event in the life cycle of the FB (Miller et al., 2003). In the recent years the interest for $\mathrm{FB}$ research has

\footnotetext{
*Corresponding author: marina.letonja@doba.si
}

DOI: $10.5937 /$ sjm16-31199 
been mostly focused on succession (e.g., Sharma, 2004; Giambatista et al., 2005; Chirico, 2008) and conflicts, also adding a new streamline of research which investigates the ambitions of possible successors that may be able to expand their career choice (i.e. to join the family business or seek employment elsewhere) with the tempting opportunity to spin off from the FB by starting their own ventures (Ljubotina et al., 2018). Nowadays interest for researching innovativeness of FB is growing (Ganzaroli et al., 2006; Laforet, 2012). Although research on innovation is gaining momentum (Calabro et. al., 2018), the activities enacted by $\mathrm{FB}$ to innovate have received less attention compared to innovation inputs and outputs (Roed, 2016; Dieleman, 2018). How FB manage innovation remains little understood, recent studies have called for research on the influence of preceding generations on successors' generations innovation behavior (Diaz-Moriana et. al., 2018). FB prosperity across generations depends on innovation (Jaskiewicz et al., 2015) to achieve long-term goals (DiazMoriana et al., 2018).

We lack research that would consider the succession process as a process of not only transferring knowledge between predecessors and successors but also to address how knowledge transfer during the succession process enhances successors and FB's innovation capacity, creativity and competitiveness. As previous research has shown, the creativity of predecessors in FB is affecting the creativity (but not innovativeness, author's note) of successors, which can be assigned to the mentoring role of family members and to the exposure to more adults in the early childhood.

Therefore, the purpose of our paper is to explore whether successors' innovativeness is positively associated with the transfer of the founders' innovativeness through knowledge transfer and creation processes in a form of the internal transfer of tacit and experiential knowledge and skills of the founders, who already early expose their children to the FB environment, are mentoring their children, supervise their apprenticeship, involve them into team work and processes of strategic planning and decision making. Second source is the external transfer of knowledge, when potential successors attend educational programs, external training, or gain working experiences in other companies.

FB with a strong heritage provide a unique bundle of resources (e.g. existing knowledge) that are potential sources of competitive advantage (Dacin et al., 2019). Since understanding of the process of creating new and using existent knowledge is of crucial importance for fostering innovations and competitiveness of a firm (Quintaine et al., 2011), we build our research on the knowledge-based view (Grant, 1996) and the organizational knowledge creating theory (Nonaka, 1994). In addition we base our research on findings of previous studies that explore knowledge as a source of innovations of individuals and firms (e.g., Delgado-Verde et al., 2011) and studies on FB succession as no general succession theory has emerged until now (Sharma et al., 2012). Creative processes include our mental functions based on our subjective emotions, values, talents, knowledge of why and knowledge of how (Ženko, 2014). We focus our research systematically and extensively on the processes of creating knowledge across family generations thereby adding new cognitions to existent body of knowledge on innovativeness and knowledge transfer 
during succession in FB (Duh, 2014; Letonja \& Duh, 2015).

The research question is: "What forms of internal and external knowledge transfer are as factors of innovativeness related to the innovativeness of successors in family businesses?" The research question from the point of view of the next generation in FB has not been researched on a global scale.

\section{INTERNAL AND EXTERNAL KNOWLEDGE TRANSFER AND HYPOTHESIS DEVELOPMENT}

One of the most crucial issues of FB' future is the transfer of ownership rights and leadership to the next family generation (Sharma et al., 2003). Especially the leadership transfer is closely linked to the selection and development of a suitable successor. Therefore, several research studies have addressed the transfer of knowledge (especially tacit one) from a predecessor to a successor (e.g., CabreraSuárez et al., 2001; Sharma, 2004) and the process of formal education and training of successors (e.g., Morris et al., 1997; Le Breton-Miller et al., 2004) as being the most crucial part of the succession process. Namely, the survival and development of a FB after the transfer to the next family generation depends not only on the readiness of the next generation to take over the leadership. Good communication is needed to build trust and this affects the success of the transfer (Saan et al., 2018). "The new generation has to add new knowledge and offer new perspectives for the sustainability of the family firm across generations" (Chirico, 2008). In order to adapt to rapidly changing environment successors should be able to "add future value to the firm by seeking new opportunities and fostering entrepreneurship" (García-Álvarez et al., 2002,). This is of crucial importance since research findings demonstrate that FB become more conservative and less innovative over time (e.g., Donckels \& Frölich, 1991; Zahra, 2005; Rondi et al., 2018), and the next generation FB often fail because of their reluctance to seek out new business opportunities (Ward, 1987). FB should leverage between preserving tradition (without losing competitiveness) and innovation (Erdogan et al., 2020). Therefore, successors should gain new knowledge not only from the predecessors but as well as through education and experiences within and outside the FB (Cabrera-Suárez et al., 2001; Chirico, 2008).

Early exposure of successors to a FB through summer and lower category jobs constitutes valuable experiences for successors (e.g., Gersick et al., 1997; Cabrera-Suárez et al., 2001). A successor may this way acquire tacit knowledge linked to a founder (e.g., Cabrera-Suárez et al., 2001) through the process of socialization (Nonaka 1994; Nonaka et al., 2000) during which a successor also becomes aware of the predecessor's mental processes, ideas, and experiences. It is of great importance that families maintain creative environments in childhood, since this is a prerequisite for creativity and innovation in a business (Ženko \& Mulej, 2011; Ženko, 2014). Acceptance and respect of child's tender emotions and needs in the family is required for the development. Emotional sensitivity is one of the more important characteristics for the development of creativity. Ideas are raw material in innovative processes and they need to be communicated in the supportive environment (Ženko, 2014). Unsuccessful ideas are not to be treated as a mistake or 
failure, but as a result, that needs to be studied for new experience and new knowledge. They are a material for new ideas that create new opportunities in innovative processes. Creative children are raised in nurturing family environment where values, culture and motivation support their creativeness and passion to aquire new knowledge.

In this context Litz and Kleysen (2001) emphasize the importance of a family culture that stimulates and facilitates innovation from the early childhood. After entering a $\mathrm{FB}$, successors should become familiar with the culture and philosophy of a FB (Mazzola et al., 2008) as well as with other aspects of the business (e.g., products, technology, suppliers, customers). Successors need to acquire knowledge about the FB's industry and management skills that enable them to influence other people (e.g., Cabrera-Suárez et al., 2001; Duh \& Belak, 2008; Mazzola et al., 2008). This can be done by mentoring and supervising relationships with the FB's leaders thereby supporting development of successors' tacit knowledge (Cabrera-Suárez et al., 2001; Chirico, 2008). Mentoring is found in the literature to be suitable for transferring critical technical and managerial skills, knowledge on managerial systems, norms, values (Swap et al., 2001). When business ethics is interpreted as individual ethics and ethics in enterprises (Dankova et al., 2014) it needs to be transferred by mentors. There are diverse opinions on whether parents are the best mentors. Some scholars believe that they are not, since they cannot give honest feedback to their children (Gersick et al., 1997) and suggest including nonfamily mentors that can teach successors how to run the FB (Ward, 1987). Tacit knowledge can be passed from the previous generation to the next family generation also in the form of apprenticeship (Chirico, 2008). However, internal apprenticeship is suitable for successors' training only in traditional industries with relatively stable environment (Chirico, 2008) and become insufficient if markets change very quickly (Le Breton-Miller et al., 2004).

Successors can learn directly from the preceding generation in a "learning-by-doing process" and "..., specially, all the "tricks of trade' related to the business" (Chirico, 2008). Through a process of "learning by doing" the "experimentation" can trigger so called internalization mode in the knowledge creating process (Nonaka, 1994). Practical training courses within a FB enable a transfer of knowledge across generations (Chirico, 2008) and help successors to understand the FB (Nonaka et al., 2000; Becerra-Fernandez \& Sabherwal, 2001), even to the extent that many successors find themselves faced with the dilemma to join FB or start their own venture (Vadnjal \& Ljubotina, 2016). This knowledge transfer and creation activities enhance a domain relevant skills and creativity relevant skills (Litz \& Kleysen, 2001). Therefore, we developed the following hypothesis:

H1: Innovativeness of successors in FB is positively associated with the transfer of founders' tacit and practical knowledge and skills on successors.

Successors' absorptive capacity, which is largely a function of the pre-existing stock of knowledge (Szulanski, 1996), is of crucial importance for assimilation of knowledge during the succession process (CabreraSuárez et al., 2001). It can be developed by both, knowledge and skills transferred from a founder and by academic and professional education. Through a process of a formal education successors gain concepts and generic skills which can be applied to most 
business contexts and enable to develop analytical skills and abilities crucial for decision making. Being part of formal education programs enables successors to get to know new ideas and trends in management and technology (Sardeshmukh \& Corbett, 2011). Research findings demonstrate that educational level has a significant impact on performance level of the next generation (Morris et al., 1997; Cabrera-Suárez et al., 2001). Successor's experiences, skills, and commitment to a FB are also important criteria in the process of selecting the most suitable successor for taking over the FB leadership (Ganzaroli et al., 2006). Therefore, we developed the following hypothesis:

H2: Innovativeness of successors in FB is positively associated with formal (academic and professional) education of successors.

Nowadays rapid changes in the FB environment require from the younger generations to be up-to-date with recent technological, product and market developments in order to improve FB innovation capability and consequently its competitiveness and performance. In order to be able to do that, several authors (Cabrera-Suárez et al., 2001; Chirico, 2008) emphasized the role of academic courses and practical training outside the FB in schools and universities. Taking part in such trainings enables successors to acquire explicit knowledge and develop "skills" that once brought into a FB and shared with other members can contribute to innovation capacity of a FB. Outside training is especially important when FB are active in the markets which have undergone fast changes (Chirico, 2008). Research studies demonstrate that more innovative $R \& D$ projects draw on greater amounts of external information than less innovative projects
(Turner \& Makhija, 2006). Younger generation has in this fast changing complex global environment the capacity to acquire knowledge of e.g. new organizational theories, technologies and skills of using social networks and media (Ženko \& Marn, 2016). Smaller enterprises have increased their funds for $R \& D$ faster than the larger ones and are now an increasingly important player in national innovation systems (Chesbrough, 2011). We have moved from the more only technology push or R\&D based innovating to more demand and technology based or open source innovative processes (e.g. Chesbrough, 2011; Ženko, 2014). While it might had been sufficient to know well one specific field, nowadays to be part of an open source innovating team we have to acquire knowledge in more than one scientific field. Due to this and rapid advancement of science the formal education and continuous learning plays an important divider.

Several authors (e.g., Ward 1987; Cabrera-Suárez et al., 2001; Chirico, 2008) suggest that successors should get experiences and skills by working outside a FB since they give them "a more detached perspective over how to run and how to introduce changes and innovations in the business" (Chirico, 2008). Successors should work outside a FB before they enter the business for full time as this enables them to develop specific abilities and to get different view on how to do business (Le BretonMiller et al., 2004; Sardeshmukh \& Corbett, 2011) as well as to be prepared for a wide range of problems that may confront their FB (Ganzaroli et al., 2006). Training and working experiences gained outside FB are of crucial importance for successors innovativeness as they offer "... exposure to new ideas and situations" (Sardeshmukh \& 
Corbett, 2011) and provide "... access to new bodies of knowledge that are relevant for the future development of firm's innovation capacity" (Ganzaroli et al., 2006). Such experiences play a crucial role in creativity and innovation processes (Litz \& Kleysen, 2001); enable successor(s) to lead the FB in a new direction (Sardeshmukh \& Corbett, 2011) and to avoid conservatism and closeness (Ganzaroli et al., 2006). Based on these findings the following two hypotheses were developed:

H3: Innovativeness of successors in FB is positively associated with successors' working experiences outside FB.

H4: Innovativeness of successors in FB is positively associated with successors' academic and practical training courses outside FB.

\section{METHODS}

We applied a quantitative empirical research approach focusing on knowledge transfer and innovativeness of successors in FB. Quantitative research started with developing two questionnaires, one for the founders and another for the successors. The questionnaires contain 5 sets of questions, in this article we used only the 4th set of questions, which contains specific questions and statements about the correlation between individual factors of knowledge transfer and innovativeness of successors. As we did not find a properly tested standard scale, we developed the questionnaire ourselves. In doing so, we used our own knowledge and the findings of various authors and turned them into statements related to innovation (Jackson, 1994; Chirico, 2008; Sardesmukh \& Corbett, 2011; Duh, 2014). We designed closed-ended questions as they enable generalization (Zelenika, 2000) although they do not allow in-depth answers, what is their weakness. However, they enable quicker answers by respondents and are easier to process. Before the research, the questionnaire was tested with the help of the target group (5 founders and successors) in order to check the understanding and aspect of the possibility of later processing of the collected data, compliance with the set hypotheses. The questionnaire was corrected accordingly before the research. We conducted a mail survey to collect data necessary to test our hypotheses. As our research includes two independent samples with mostly ordinal data, we used univariate (analysis of means, variance, reliability index Cronbach alpha) and multivariate (correlation) statistical methods to test our hypotheses.

We used the coefficient Cronbach alpha to test the reliability of the variables involved. The Cronbach alpha values range on the interval from 0 to 1 ; higher values show a better reliability, acceptable are values between 0.60 and 0.95; Cronbach alpha, lower than 0.50 is unacceptable (Bhattacherjee, 2012). The Pearson correlation coefficient was used to test the strength of dependency (not causality) between the variables. In social studies, we are usually satisfied with $5 \%(0.05)$ or even $10 \%(0.10)$ precision, which means that correlation is significant at the 0,05 level (2 tailed) or at the 0,10 level (2 tailed) (Hussey \& Hussey, 1997).

\subsection{Sample and data sources}

The sample is randomly handy. The FB database has been collected by the authors for several years (data from the media, personal contacts, data from the Ajpes 
database, the snowball method). In the second group of FB (20.4\%), Questionnaires were sent to over 400 micro, successors are already formally involved in small and medium-sized FB in Slovenia. We the FB and they are employed, the received 159 questionnaires from the successors and 175 questionnaires from founders, but only 103 were fully completed questionnaires from the same FB reflecting a response rate of $25 \%$ that is higher than rates reported in other FB studies. The survey was partly anonymous. In the event that the founders and successors did not wish to disclose the name of the FB, we asked them to provide the same code for the FB. In addition, due to the possibility of comparing the answers, the questionnaires were appropriately marked so that the answers from the same company were identified. Most of the participants provided the name of FB, which later enabled further research in the direction of the connection between innovation and the FB performance. The hypotheses were tested by analyzing data from the successor database, using the correlation method. The size of a company was defined only by applying the measure of the average number of employees in the business year. The FB was defined as a business where the founder / owner/ manager considers the business as a family one. Therefore, the first question in our questionnaire was, "do you consider your firm as a family firm?". All 103 respondents reported being a $\mathrm{FB}$.

The average age of FB in our research is 23.5 years. In the sample, we grouped FB into two groups - FB of the first generation and FB of the second generation. In the first group of FB $(79.6 \%)$, the founders are strongly involved into management and daily operations of the FB, they are active and employed, while successors are already involved, but not actively, they are students and pupils and not employed yet in the FB. management and ownership of the FB was already partly or entirely transferred from the founders to the successors, while founders are retired, but still active in a FB. The structure of the first and second FB group reflects to great extent the structure of FB in Slovenia regarding a family generation in charge where the first generation FB prevail approaching the transfer of leadership and ownership rights in the near future (Mandl, 2008; Duh, 2009). The male founders dominate the sample, while less than $20 \%$ of the sample are female founders. Also among successors, male successors prevail, while female successors are presented by almost two fifths. Most of the founders finished technical high school or vocational school, while most of the successors finished bachelor degree in business or a high school. Most of the successors do not have previous working experience in other companies (43.7 $\%)$. The average number of employees is 30 ; on average three family members are employed. The FB from service industries dominate our sample $-46.6 \%$, followed by production FB - $27.2 \%$ and trading FB $26.2 \%$.

\subsection{Measures}

\subsubsection{Dependent variable}

We measured innovativeness of successors with the help of Douglas N. Jackson's personality inventory (JPI, Jackson Personality Inventory), which was adapted by Mueller and Thomas (2001) from Jackson (1994). JPI is a measure of the propensity to innovativeness and conceptually it is synonymous for creativity. Innovativeness 
scale is very similar to the various indicators of the creative personal style for different types of personalities, especially to the subscale of originality by Kirton Adaption Innovation (KAI) (Mueller \& Thomas, 2001). JPI, in which innovativeness is defined as the tendency to think and act creatively, uses this construct, because the innovativeness, creativity and initiative are defined as one of the permanent characteristics of entrepreneurs (Mueller \& Thomas, 2001). Definition of the individual who reaches on a scale JPI (Jackson, 1994) higher number of points is that it is creative and inventive individual, capable of original thinking, motivated to develop new solutions to problems, that appreciates new ideas, likes to improvise. Studies have confirmed the reliability and validity of JPI to measure the generalized risk-taking (Jackson, 1994). Further research has also supported reliability and the validity of the scale JPI (Sexton \& Bowman, 1984; Jackson, 1994). In the scale for measuring innovativeness of a successor in our research we used 11 variables, including all eight variables/assertions from the JPI scale. The coefficient of reliability (Cronbach alpha) is 0.764 , which means that the reliability of the construct of innovativeness of successors is good (coefficient between 0.70 and 0.90 ).

\subsubsection{Independent variables}

In our survey independent variables are constructs associated with the dependent variable innovativeness of successors in FB and are: tacit and practical knowledge and skills of the founder, formal education of the successor, working experiences of the successor in another company and academic and practical courses attended by the successor outside the FB. The value of the
Cronbach alfa coefficients for all the constructs varies from 0.891 to 0.904 , which means that the reliability of the constructs is good.

\section{EXPERIMENTAL (RESEARCH) RESULTS}

In our research we measured the constructs of knowledge transfer by asking the successors to assign the importance of individual forms of internal and external knowledge transfer; as well, we asked them about the actual experiences with different forms of internal knowledge transfer. In total, we used 28 variables (Table 1).

Results in Table 1 show that the highest importance was given to learning by doing and to participation in decision making and strategic planning, while the least importance was assigned to apprenticeship. On the other side, successors find mentoring of the parent and working together with the parent as the most important actually performed forms of transfer of tacit and practical knowledge and skills of the founder in relation to their innovativeness. Among the forms of the external knowledge transfer, the highest impact for innovativeness of successors is assigned to formal education, which is enabling knowledge in the areas of critical thinking, creativity, communication, customer focus and teamwork and the least importance is assigned to formal education promoting mastering managerial concepts and their application in practice. The highest importance for innovativeness of successors within the construct of outside working experiences is assigned to work experience, which give the successor a special view to the introduction and implementation of change and innovation in the company. 
Table 1. Variables of internal and external transfer of knowledge to the successor

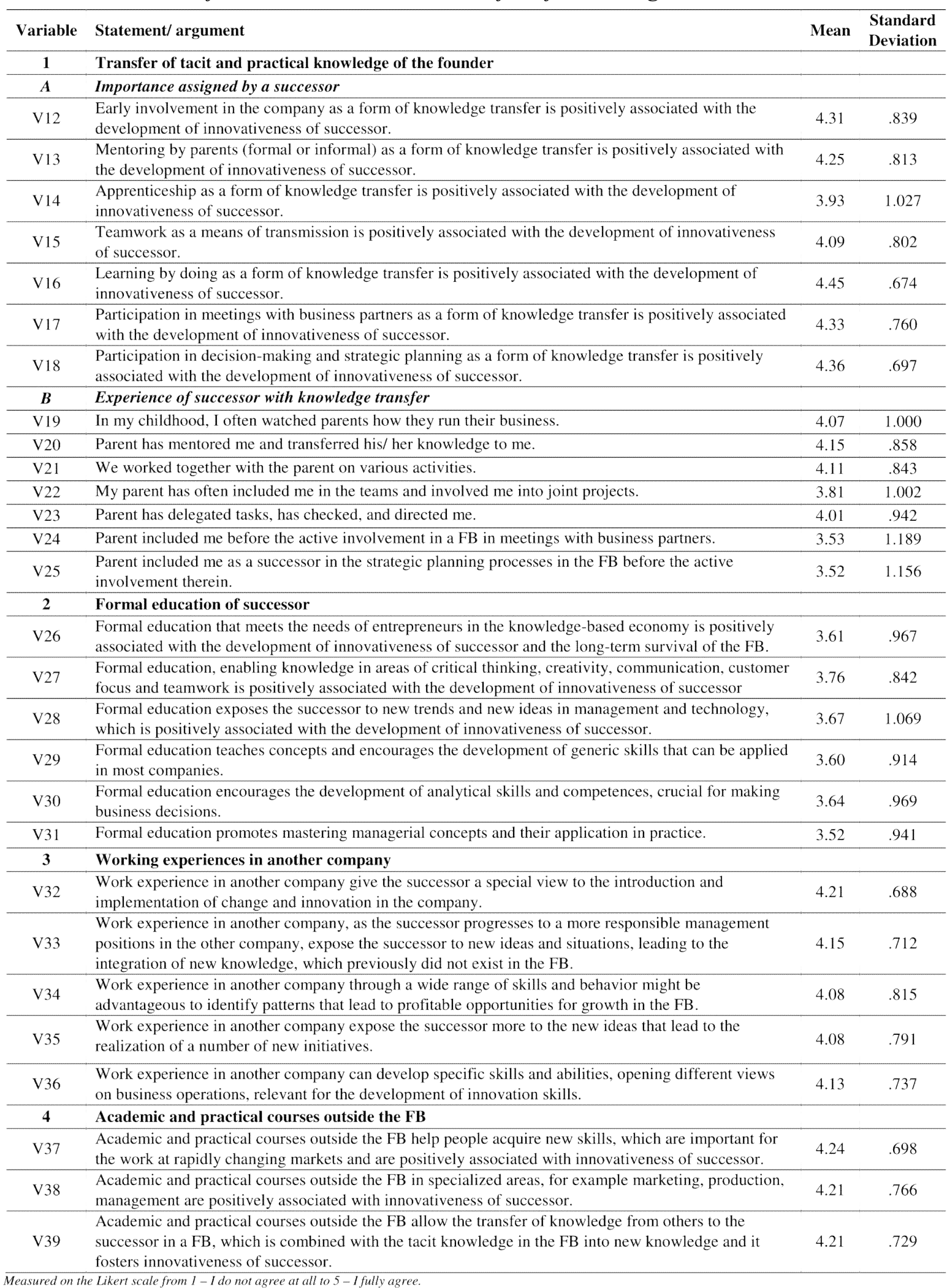


Table 2. Correlation between successors' innovativeness and the importance of transferring the founder's tacit and practical knowledge and skills to a successor

\begin{tabular}{|c|c|c|c|c|c|c|c|c|}
\hline $\begin{array}{l}\text { Innovativeness } \\
\text { of successors }\end{array}$ & & V12 & V13 & V14 & V15 & V16 & V17 & V18 \\
\hline \multirow{3}{*}{$\begin{array}{l}\text { I often surprise } \\
\text { with novel ideas } \\
\text { (V1) }\end{array}$} & $\begin{array}{l}\text { Pearson } \\
\text { Correlation }\end{array}$ & $.342^{* *}$ & $.208^{*}$ & .148 & $.223^{*}$ & $.326^{* *}$ & $.224^{*}$ & .112 \\
\hline & $\begin{array}{l}\text { Sig. (2- } \\
\text { tailed) }\end{array}$ & .000 & .038 & .142 & .025 & .001 & .024 & .265 \\
\hline & $\mathrm{N}$ & 101 & 100 & 100 & 101 & 101 & 101 & 101 \\
\hline \multirow{3}{*}{$\begin{array}{l}\text { I am often being } \\
\text { asked to help } \\
\text { people in creative } \\
\text { activities (V2) }\end{array}$} & $\begin{array}{l}\text { Pearson } \\
\text { Correlation }\end{array}$ & $.222^{*}$ & .032 & $.274^{* *}$ & .170 & .153 & $.276^{* *}$ & $.207^{\prime}$ \\
\hline & $\begin{array}{l}\text { Sig. (2- } \\
\text { tailed) }\end{array}$ & .028 & .755 & .006 & .093 & .130 & .006 & .040 \\
\hline & $\mathrm{N}$ & 99 & 98 & 98 & 99 & 99 & 99 & 99 \\
\hline \multirow{3}{*}{$\begin{array}{l}\text { I am a very } \\
\text { creative person } \\
\text { (V7) }\end{array}$} & $\begin{array}{l}\text { Pearson } \\
\text { Correlation }\end{array}$ & $.350^{* *}$ & .195 & .120 & .103 & $.211^{*}$ & $.284^{* *}$ & .155 \\
\hline & $\begin{array}{l}\text { Sig. (2- } \\
\text { tailed) }\end{array}$ & .000 & .052 & .234 & .305 & .034 & .004 & .122 \\
\hline & $\mathrm{N}$ & 101 & 100 & 100 & 101 & 101 & 101 & 101 \\
\hline \multirow{3}{*}{$\begin{array}{l}\text { I like to } \\
\text { experiment with } \\
\text { different styles of } \\
\text { doing the same } \\
\text { things (V8) }\end{array}$} & $\begin{array}{l}\text { Pearson } \\
\text { Correlation }\end{array}$ & $.252^{*}$ & .175 & .100 & $.246^{*}$ & $.254^{*}$ & $.296^{* *}$ & .152 \\
\hline & $\begin{array}{l}\text { Sig. (2- } \\
\text { tailed) }\end{array}$ & .011 & .082 & .324 & .013 & .010 & .003 & .130 \\
\hline & $\mathrm{N}$ & 101 & 100 & 100 & 101 & 101 & 101 & 101 \\
\hline \multirow{5}{*}{$\begin{array}{l}\text { In the recent } 5 \\
\text { years I developed } \\
\text { / started to } \\
\text { market } 0,1,2,3 \text { - } \\
5, \text { more than } 5 \\
\text { new lines of } \\
\text { products and } \\
\text { services (V9) }\end{array}$} & $\begin{array}{l}\text { Pearson } \\
\text { Correlation }\end{array}$ & .198 & .124 & .084 & $.209^{*}$ & .197 & .146 & .223 \\
\hline & $\begin{array}{l}\text { Sig. (2- } \\
\text { tailed) }\end{array}$ & .062 & .246 & .436 & .048 & .062 & .170 & .034 \\
\hline & $\mathrm{N}$ & 90 & 89 & 89 & 90 & 90 & 90 & 90 \\
\hline & $\begin{array}{l}\text { Sig. (2- } \\
\text { tailed) }\end{array}$ & .119 & .607 & .261 & .058 & .095 & .089 & .063 \\
\hline & $\mathrm{N}$ & 85 & 85 & 84 & 85 & 85 & 85 & 85 \\
\hline \multirow{3}{*}{$\begin{array}{l}\text { In the recent } 5 \\
\text { years the changes } \\
\text { in production / } \\
\text { services/ process } \\
\text { lines... (V11) }\end{array}$} & $\begin{array}{l}\text { Pearson } \\
\text { Correlation }\end{array}$ & .078 & -.087 & .170 & $.276^{* *}$ & .176 & .034 & .134 \\
\hline & $\begin{array}{l}\text { Sig. }(2- \\
\text { tailed) }\end{array}$ & .468 & .422 & .114 & .009 & .101 & .754 & .214 \\
\hline & $\mathrm{N}$ & 88 & 88 & 88 & 88 & 88 & 88 & 88 \\
\hline
\end{tabular}

Variables within the construct of academic and practical courses outside the FB are given by successors almost the same importance in relation to their innovativeness.

The research results (Table 2) show 17 statistically significant (at $\mathrm{p}<0.05)$ positive, mostly weak to sometimes even mediumstrong correlations. Positive medium strong correlation is shown between innovativeness of successors, as measured by "I often surprise by novel ideas" (V1) and the importance given by the successors to the "early involvement in the company as a form of knowledge transfer" (V12) and "learning by doing as a form of knowledge transfer" (V16). Among the innovativeness of successors, as measured by the "I'm a very creative person" (V7) and the importance that successors give to "early involvement in the company as a form of knowledge transfer" (V12) there is a positive medium strong correlation.

In Tables 2-5 we present only the factors of innovativeness that correlate with different forms of knowledge transfer. 
Table 3. Correlation between successors' innovativeness and actually performed transfer of founder's tacit and practical knowledge and skills to a successor

\begin{tabular}{|c|c|c|c|c|c|c|c|c|}
\hline $\begin{array}{l}\text { Innovativeness of } \\
\text { successors }\end{array}$ & & V19 & V20 & V21 & $\mathrm{V} 22$ & V23 & V24 & V25 \\
\hline \multirow{3}{*}{$\begin{array}{l}\text { Usually I do not continue } \\
\text { with work as I was used to } \\
\text { do (V5) }\end{array}$} & $\begin{array}{l}\text { Pearson } \\
\text { Correlation }\end{array}$ & .023 & -.071 & -.062 & .059 & $\begin{array}{r}- \\
.054\end{array}$ & .178 & $.214^{*}$ \\
\hline & $\begin{array}{l}\text { Sig. (2- } \\
\text { tailed) }\end{array}$ & .817 & .480 & .535 & .556 & .594 & .076 & .033 \\
\hline & $\mathrm{N}$ & 101 & 101 & 101 & 101 & 101 & 100 & 100 \\
\hline \multirow{3}{*}{$\begin{array}{l}\text { In the recent } 5 \text { years I } \\
\text { developed / started to } \\
\text { market } 0,1,2,3-5 \text {, more } \\
\text { than } 5 \text { new lines of } \\
\text { products and services (V9) }\end{array}$} & $\begin{array}{l}\text { Pearson } \\
\text { Correlation }\end{array}$ & $.370^{* *}$ & $.214^{*}$ & $.316^{* *}$ & $.298^{* *}$ & .139 & $.414^{* *}$ & $.330^{* *}$ \\
\hline & $\begin{array}{l}\text { Sig. (2- } \\
\text { tailed) }\end{array}$ & .000 & .042 & .002 & .004 & .188 & .000 & .001 \\
\hline & $\mathrm{N}$ & 91 & 91 & 91 & 91 & 91 & 90 & 90 \\
\hline \multirow{3}{*}{$\begin{array}{l}\text { In the recent } 5 \text { years I } \\
\text { developed / started to } \\
\text { market } 0,1,2,3-5 \text {, more } \\
\text { than } 5 \text { new processes } \\
\text { (V10) }\end{array}$} & $\begin{array}{l}\text { Pearson } \\
\text { Correlation }\end{array}$ & $.261^{*}$ & $.226^{*}$ & $.286^{* *}$ & $.237^{*}$ & .188 & $.303^{* *}$ & .213 \\
\hline & $\begin{array}{l}\text { Sig. (2- } \\
\text { tailed) }\end{array}$ & .015 & .037 & .008 & .028 & .083 & .005 & .050 \\
\hline & $\mathrm{N}$ & 86 & 86 & 86 & 86 & 86 & 85 & 85 \\
\hline \multirow{3}{*}{$\begin{array}{l}\text { In the recent } 5 \text { years the } \\
\text { changes in production / } \\
\text { services/ process lines... } \\
\text { (V11) }\end{array}$} & $\begin{array}{l}\text { Pearson } \\
\text { Correlation }\end{array}$ & $.251^{*}$ & $.265^{*}$ & $.283^{* *}$ & .196 & .083 & $.240^{*}$ & .180 \\
\hline & $\begin{array}{l}\text { Sig. (2- } \\
\text { tailed) }\end{array}$ & .018 & .012 & .008 & .067 & .445 & .025 & .096 \\
\hline & $\mathrm{N}$ & 88 & 88 & 88 & 88 & 88 & 87 & 87 \\
\hline
\end{tabular}

In the case of actually performed forms of knowledge transfer from the founder to the successor and correlation with innovativeness of successors, we found 15 statistically significant $($ at $\mathrm{p}<0.05)$ positive, mostly weak to sometimes even mediumstrong correlations (Table 3 ). Innovativeness of successor medium strong correlates with the following forms of actual transfer of knowledge: "early involvement in the company" (V12), "apprenticeship as a form of knowledge transfer" (V14), "involvement in meetings with business partners as a form of knowledge transfer" (V17), "participation in decision-making and strategic planning as a form of knowledge transfer" (V18). Therefore, our hypothesis $\mathrm{H1}$ : "Innovativeness of successors in $F B$ is positively associated with the transfer of founders' tacit and practical knowledge and skills to successors," was partly confirmed.

The survey revealed that between the innovativeness of successors and successor's formal education (e.g. in the field of entrepreneurship) there is no positive correlation. The result of the correlation, if we take into consideration the relatively good level of education of successors is surprising. Therefore, the hypothesis $\mathrm{H} 2$ : "Innovativeness of successors in $F B$ is positively associated with formal (academic and professional) education of successors," was not confirmed.

In the case of working experience in another company and its correlation with innovativeness of successors, we found 9 statistically significant (at $\mathrm{p}<0.05)$ positive, mostly weak to sometimes even mediumstrong correlations (Table 4). Innovativeness of successors mainly relates medium strong to work experience of successors in another company "which gives the successor a special view to the introduction and implementation of changes and innovation in the FB" (V32), "work experience in another company expose the successor more to the 
Table 4. Correlation between successors' innovativeness and working experiences of successors outside the FB

\begin{tabular}{|c|c|c|c|c|c|c|}
\hline Innovativeness of successors & & V32 & V33 & V34 & V35 & V36 \\
\hline \multirow[t]{3}{*}{$\begin{array}{l}\text { I often surprise with novel } \\
\text { ideas (V1) }\end{array}$} & $\begin{array}{l}\text { Pearson } \\
\text { Correlation }\end{array}$ & $.288^{* *}$ & .062 & .081 & .057 & .171 \\
\hline & Sig. (2-tailed) & .006 & .574 & .463 & .599 & .109 \\
\hline & $\mathrm{N}$ & 91 & 85 & 85 & 87 & 89 \\
\hline \multirow{3}{*}{$\begin{array}{l}\text { I am often being asked to help } \\
\text { people in creative activities } \\
\text { (V2) }\end{array}$} & $\begin{array}{l}\text { Pearson } \\
\text { Correlation }\end{array}$ & $.254^{*}$ & .019 & .079 & .144 & .115 \\
\hline & Sig. (2-tailed) & .016 & .866 & .480 & .190 & .290 \\
\hline & $\mathrm{N}$ & 89 & 83 & 83 & 85 & 87 \\
\hline \multirow{3}{*}{$\begin{array}{l}\text { I am more satisfied if I develop } \\
\text { a novel idea as if I master a } \\
\text { skill (V3) }\end{array}$} & $\begin{array}{l}\text { Pearson } \\
\text { Correlation }\end{array}$ & .189 & .113 & .076 & .057 & $.230^{\circ}$ \\
\hline & Sig. (2-tailed) & .072 & .298 & .487 & .600 & .029 \\
\hline & $\mathrm{N}$ & 91 & 86 & 86 & 88 & 90 \\
\hline \multirow{3}{*}{$\begin{array}{l}\text { In the recent } 5 \text { years I } \\
\text { developed / started to market } 0 \text {, } \\
1,2,3-5 \text {, more than } 5 \text { new } \\
\text { processes (V10) }\end{array}$} & $\begin{array}{l}\text { Pearson } \\
\text { Correlation }\end{array}$ & $.337^{* *}$ & .186 & .205 & .198 & $.307^{* *}$ \\
\hline & Sig. (2-tailed) & .003 & .117 & .084 & .090 & .007 \\
\hline & $\mathrm{N}$ & 77 & 72 & 72 & 74 & 76 \\
\hline \multirow{3}{*}{$\begin{array}{l}\text { In the recent } 5 \text { years the } \\
\text { changes in production / } \\
\text { services/ process lines... (V11) }\end{array}$} & $\begin{array}{l}\text { Pearson } \\
\text { Correlation }\end{array}$ & $.237^{*}$ & .164 & .144 & .115 & $.248^{*}$ \\
\hline & Sig. (2-tailed) & .037 & .168 & .225 & .328 & .031 \\
\hline & $\mathrm{N}$ & 78 & 72 & 73 & 74 & 76 \\
\hline
\end{tabular}

Table 5. Correlation between successors' innovativeness and academic and practical courses outside the FB

\begin{tabular}{|c|c|c|c|c|}
\hline Innovativeness of successors & & V37 & V38 & V39 \\
\hline \multirow[t]{3}{*}{ I often surprise with novel ideas (V1) } & Pearson Correlation & .102 & $.223^{*}$ & $.274^{* *}$ \\
\hline & Sig. (2-tailed) & .317 & .026 & .006 \\
\hline & $\mathrm{N}$ & 99 & 100 & 99 \\
\hline \multirow{3}{*}{$\begin{array}{l}\text { I am often being asked to help people in creative } \\
\text { activities (V2) }\end{array}$} & Pearson Correlation & .093 & .153 & $.200^{*}$ \\
\hline & Sig. (2-tailed) & .364 & .133 & .048 \\
\hline & $\mathrm{N}$ & 97 & 98 & 98 \\
\hline \multirow[t]{3}{*}{ I am a very creative person (V7) } & Pearson Correlation & .155 & $.237^{*}$ & $.291^{* * *}$ \\
\hline & Sig. (2-tailed) & .125 & .018 & .003 \\
\hline & $\mathrm{N}$ & 99 & 100 & 99 \\
\hline \multirow{3}{*}{$\begin{array}{l}\text { I like to experiment with different styles of doing } \\
\text { the same things (V8) }\end{array}$} & Pearson Correlation & .075 & .186 & $.237^{*}$ \\
\hline & Sig. (2-tailed) & .459 & .064 & .018 \\
\hline & $\mathrm{N}$ & 99 & 100 & 99 \\
\hline \multirow{3}{*}{$\begin{array}{l}\text { In the recent } 5 \text { years I developed / started to market } \\
0,1,2,3-5 \text {, more than } 5 \text { new lines of products and } \\
\text { services (V9) }\end{array}$} & Pearson Correlation & .159 & $.226^{*}$ & .153 \\
\hline & Sig. (2-tailed) & .139 & .033 & .155 \\
\hline & $\mathrm{N}$ & 88 & 89 & 88 \\
\hline \multirow{3}{*}{$\begin{array}{l}\text { In the recent } 5 \text { years I developed / started to market } \\
0,1,2,3-5, \text { more than } 5 \text { new processes (V10) }\end{array}$} & Pearson Correlation & $.250^{*}$ & $.243^{*}$ & .204 \\
\hline & Sig. (2-tailed) & .023 & .026 & .065 \\
\hline & $\mathrm{N}$ & 83 & 84 & 83 \\
\hline \multirow{3}{*}{$\begin{array}{l}\text { In the recent } 5 \text { years the changes in production / } \\
\text { services/ process lines... (V11) }\end{array}$} & Pearson Correlation & $.217^{*}$ & .167 & .200 \\
\hline & Sig. (2-tailed) & .045 & .122 & .065 \\
\hline & $\mathrm{N}$ & 86 & 87 & 86 \\
\hline
\end{tabular}


new ideas that lead to the realization of a number of new initiatives" (V35) and "work experience in another company can develop specific skills and abilities, opening different views on business operations, relevant for the development of innovation skills" (V36). Therefore, we can partially confirmed the hypothesis H3:"Innovativeness of successors in FB is positively associated with successors' working experiences outside FB."

In the case of academic and practical courses attended by successors outside the FB and innovativeness of successors, we found 10 statistically significant (at $\mathrm{p}<0.05$ ) positive correlations, which are all weak (Table 5). Most correlations exist between innovativeness of successors, measured by the variables "creativity of successors" (V7), "their willingness to experiment with different ways of doing the same things"(V8) and "I often surprise with novel ideas" (V1) and the variable "academic and practical courses outside the FB allow the transfer of knowledge from others to the successor in a $\mathrm{FB}$, which is combined with the tacit knowledge in the FB into new knowledge and it fosters innovativeness of successor" (V39). Therefore, we partially confirmed the hypothesis H4: "Innovativeness of successors in FB is positively associated with successors' academic and practical training courses outside FB."

\section{DISCUSSION}

Our research revealed that only two forms of the transfer of founders' tacit and practical knowledge and skills were recognized by successors to be of importance for their innovativeness, namely early involvement of the successors in the FB and learning by doing. Regarding actually performed forms of transfer of founders' tacit and practical knowledge and skills, the survey showed positive medium strong correlations between innovativeness of successors and early involvement in the FB, apprenticeship, including successors in meetings with business partners and cooperation of successors in decision-making and strategic planning prior to their active involvement in the operation of the FB.

Our research results coincide with previous research findings (e.g., Gersick et al., 1997; Cabrera-Suárez et al., 2001) on the importance of early involvement of the successors into the environment of FB, which was found to be a valuable experience allowing successors to obtain founders' tacit knowledge, but are new with regard to the successors' innovativeness. And, learning by doing as well as apprenticeships are being confirmed by our research to positively influence successors' innovativeness. These forms of knowledge transfer enable successors to better understand the technical field and acquire valuable tacit knowledge of founders, often unconsciously (e.g., Le Breton-Miller et al. 2004; Chirico, 2008). Other forms of family members work on joint activities in FB such as integrating successors in meetings with business partners, in the decision-making processes and strategic planning, even before the active involvement of the successors in the FB, are also given high importance for the innovativeness of successors. These forms of knowledge transfer enable successors a better understanding of the founders' formal and informal networks, opening horizons and encourage curiosity of successors for all that is new in the external environment of FB. Meetings with business partners are a valuable source of tacit knowledge of 
customers and suppliers, which can be incorporated into new concepts, technologies, products, systems, which encourage successors' creativity and innovativeness.

Successors in our study highly evaluated the importance of formal education for their innovativeness; particularly they underlined the importance of formal education (e.g. in entrepreneurship), which gives them knowledge of critical thinking, creativity, communication, customer focus and teamwork. But the results of correlation in our research show that formal education of successors is not positively correlated with successors' innovativeness, which does not confirm theoretical assumptions. Studies in the past have highlighted the importance of formal education of successors for success of FB after the transfer to the next generation (Cabrera-Suárez et al., 2001; PerezGonzalez, 2006). If you want to be competitive, you have to be able to create new knowledge and you have to be innovative. Successors in FB examined in our study are on average better educated than their parents, the founders.

Our research results confirmed that working experiences of successors in another company are recognized as important for their innovativeness. These experiences are especially valuable, because in this way successors get new knowledge about markets, technologies and industry (CabreraSuárez et al., 2001; Sardesmukh \& Corbett, 2011). Our research showed that most of the successors in FB do not have this important previous working experience. We associate these findings with a long period of recession in Slovenia after 2008, when the economic crisis began.

The survey results partially confirmed that academic and practical courses of successors outside the FB are positively associated with their innovativeness. Successors assigned the highest importance for their innovativeness to the new skills, which are important for the functioning on the rapidly changing markets (Zehrer \& Leiss, 2020). The academic and practical courses outside the FB are in the literature on family business considered as very important for the development of successors, enabling them to acquire new skills. They are essential when FB are operating in markets undergoing rapid changes (Cabrera-Suárez et al., 2001; Chirico, 2008) and play a key role in the innovation processes (Litz \& Kleysen, 2001). The findings of our survey coincide with some of the findings of the studies referred to in the past, but are new from the aspect of successors' innovativeness.

\section{CONCLUSION}

The results of our research reveal that when the actual forms of internal knowledge transfer are discussed the positive correlations exist between innovativeness of successors and their early inclusion into FB, apprenticeship, inclusion of successors into meetings with business partners and strategic planning before they get involved into a FB. Regarding the external knowledge transfer the research revealed that formal education is not positively correlated to the innovativeness of successors, while the external training and working experiences in other companies are.

Since family businesses are important in many national economies worldwide, we find the recognition of factors that enhance their innovativeness and innovativeness of their key stakeholders as an important economic and policy issue for economic 
growth and prosperity.

We developed a new conceptual model for assessment and development of innovativeness of successors in FB. Practical implications of our research findings are useful for founders and successors of FB by demonstrating the most effective and efficient forms of transferring the existing knowledge and creating new knowledge thus fostering innovations; and for policy makers and institutions that work with FB (e.g., consulting agencies, chambers of commerce) which should put more attention to raising founder's awareness of the importance of knowledge transfer/creation processes during the whole process of transferring a FB.

The focus and thus limitation of our research is on intergenerational family succession (from the first - founding, to the second generation) in smaller FB, as research findings show that the majority of small FB' leaders prefer to realize succession within a family circle (e.g., Le Breton-Miller et al., 2004).

The study was conducted on a sample of 103 smaller FB. Among these were 82 FB of the first generation and $21 \mathrm{FB}$ of the second generation. A survey on a sample with more equal representation of FBs of both generations shall be considered. We studied seven forms of knowledge transfer from the founder to the successor, not the differences between them and their impact on innovativeness of successor. It would be interesting to examine the differences between formal and informal mentoring of parents, and/or an external expert, and how this affects innovativeness of successor.

We studied the positive correlation, not causality between variables. The challenge for future research is the use of the SEM (Structural Equation Modelling) and thereby further statistical processing of data in the databases of the founders and successors in FB in Slovenia.

\section{References}

Becerra-Fernandez, I., \& Sabherwal, R. (2001). Organizational Knowledge Management: A Contingency Perspective. Journal of Management Information Systems, 18 (1), 23-55.

Bhattacherjee, A. (2012). Social Science Research: Principles, Methods, and Practices. Scotts Valley, California, US: CreateSpace

Cabrera-Suárez, K., De Saa-Pérez, P., \& García-Almeida, D. (2001). The Succession Process from a Resource and Knowledgebased View of the Family Firm. Family Business Review, 14 (1), 37-46.

Calabro, A., Vecchiarini, M, Gast, J., Campopiano, G., De Massis, A., \& Kraus, S. (2018). Innovation in family firms: A systematic literature review and guidance for future research, International Journal of management reviews, 21 (3), 317-355.

Chesbrough, H. W. (2011). Open Services Innovation: Rethinking Your Business to Grow and Compete in a New Era. San Francisco, US: Jossey-Bass.

Chirico, F. (2008). Knowledge Accumulation in Family Firms: Evidence from Four Case Studies. International Small Business Journal, 26 (4), 433-462.

Dacin, M.T., Dacin, P.A., \& Keet, D. (2019). Tradition in organizations: A custodianship framework. Academy of management annals, 13 (1), 342-373.

Dankova, P., Valeva, M., \& Štrukelj, T. (2015). A comparative analysis of international corporate social responsibility standards as enterprise policy/governance 


\title{
ТРАНСФЕР ЗНАЫА ЗА ИНОВАТИВНОСТ У ПОРОДИЧНИМ ПРЕДУЗЕЋИМА
}

\author{
Marina Letonja, Mojca Duh, Zdenka Ženko
}

\begin{abstract}
Извод
Породична предузећа (ПП) су важна у већини националних економија. У овом раду, истраживано је да ли је иновативност наследника позитивно повезана са преносом иновативности оснивача, кроз трансфер знања и процес креације у облику интерног преноса тацитних и искуствених знања и вештина оснивача; као и са спољним трансфером знања, када су потенцијални наследници похађали образовне програме, екстерну обуку или су стекли радно искуство у другим компанијама. Ово истраживање открива да када се ради о стварним облицима интерног преноса знања, постоје позитивне корелације између иновативности наследника и њиховог раног укључивања у ПП, шегртовања, укључивања наследника на састанке са пословним партнерима и стратешког планирања пре него што се укључе у ПП. Истраживање је делимично потврдило да су у погледу спољног преноса знања радно искуство наследника у другим компанијама и учешће на академским курсевима позитивно повезани са њиховом иновативношћу.
\end{abstract}

Кључне речи: породично предузеће, иновација, трансфер знања, сукцесија

innovation guidelines. Systems research and behavioral science, 32 (2), 152-159.

Delgado-Verde, M., Martín-de Castro, G., \& Navas-López, J. E. (2011). Organizational knowledge assets and innovation capability: Evidence form Spanish manufacturing firms. Journal of Intellectual Capital, 12 (1), 5-19.

Diaz-Moriana, V., Clinton, E., Kammerlander, N., Lumpkin, G.T., \& Craig, J.B. (2018). Innovation motives in family firms: A transgenerational view. Entrepreneurship theory and practice, 16 (3), 104225871880305.

Dieleman, M. (2018). Reaping what you sow: The family firm innovation trajectory. Journal of family business strategy. Advance online publication.

Doi: 10.1016/j.jfbs.2018.03.003.

Donckels, R., \& Fröhlich, E. (1991). Sind Familienbetriebe wirklich anders? Europäische STRATOS-Erfahrungen.
Internationales Gewerbearchiv, 4, 219-235.

Duh, M., \& Belak, J. (2008). Special knowledge needs of family enterprises in transition economies: experiences from Slovenia. Knowledge Management Research \& Practice, 6 (3), 187-198.

Duh, M. (2009). Distinctive characteristics of family business and supporting infrastructure: comparison of Slovenia with EU and other countries. In: K. Širec (Ed.), Dynamics of Slovenian entrepreneurship: Slovenian entrepreneurship observatory 2008 (pp. 105121). Maribor: FEB.

Duh, M. (2014). Family business succession as knowledge creation process. Kybernetes, 43 (5), 699 - 714.

Erdogan, I., Rondi, E., \& De Massis, A. (2020). Managing the tradition and Innovation paradox in family firms: A family imprinting perspective. Entrepreneurship 
theory and practice, 44 (1), 20-54.

European Family Businesses. Facts and Figures. (2017). http://www.europeanfamilybusiness es.eu/ Accessed 30. 1. 17.

Ganzaroli, A., Fiscato, G., \& Pilotti, L., (2006). Does business succession enhance firm's innovation capacity? Results from an exploratory analysis in Italian SMEs. Working paper n.2006-29, 2nd Workshop on Family Firm Management Research. Nice, $\begin{array}{llllll}\mathrm{I} & \mathrm{t} & \mathrm{a} & 1 & \mathrm{y}\end{array}$. http://ideas.repec.org/p/mil/wpdepa/2006.29 .html/ Accessed 5. 2. 14.

García-Álvarez, E., López-Sintas, J., \& Gonzalvo, P.S. (2002). Socialization Patterns of Successors in First- to Second-Generation Family Businesses. Family Business Review, 15 (3), 189-203.

Gersick, K.E., Davis, J.A., McCollom Hampton, M., \& Lansberg, I. (1997). Generation to Generation. Life Cycles of the Family Business. Boston, US: Harvard Business School Press.

Giambatista, R. C., Rowe, W. G., \& Riaz, S. (2005). Nothing Successeds Like Succession: A Critical Review of Leader Succession Literature Since 1994. The Leadership Quarterly, 16 (6), 963-991.

Grant, R. M. (1996). Toward a Knowledge-based Theory of the Firm. Strategic Management Journal, 17 (Winter Special Issue), 109-122.

Hussey, J., \& Hussey, R. (1997). Business Research: A Practical Guide for Undergraduate and Postgraduate Students. Hamphsire, UK: Palgrave.

Jackson, D.N. (1994). Jackson Personality Inventory-Revised Manual. Port Heron, MI, US: Sigma Assessment Systems, Inc.

Jaskiewicz, P., Combs, J.G., \& Rau, S.B. (2015). Entrepreneurial legacy : Toward a theory of how some family firms nurture transgenerational entrepreneurship. Journal of business venturing, 30 (1), 29-49.

Laforet, S. (2012). Innovation in small family businesses. Cheltenham: Edward Elgar.

Le Breton-Miller, I., Miller, D., \& Steier, L.P. (2004). Toward an Integrative Model of Effective FOB Succession. Entrepreneurship Theory and Practice, 28 (3), 305-328.

Letonja, M., \& Duh, M. (2015). Knowledge transfer in family businesses and its effects on the innovativeness of the next family generation. Knowledge management research and practice, 14 (2), 213-224.

Litz, R. A., \& Kleysen, R. F. (2001). Your old Men Shall Dream Dreams, Your Young Men Shall See Visions: Toward a Theory of Family Firm Innovation with Help from the Brubeck Family. Family Business Review, 14 (4), 335-352.

Ljubotina, P., Gomezelj, D., Vadnjal, J. (2018). Succeeding a family business in a transition economy: following business goals or do it in my own way? Serbian Journal of Management, 13 (1), 29-46.

Mandl, I. (2008). Overview of Family Business Relevant Issues. Final Report, Austrian Institute for SME Research, $\mathrm{V} \quad \mathrm{i} \quad \mathrm{e} \quad \mathrm{n} \quad \mathrm{n} \quad \mathrm{a}$. http://ec.europa.eu/enterprise/entrepreneursh i

p/craft/family_business/family_business_en. htm/ Accessed 31. 07. 09.

Mazzola, P., Marchision, G., \& Astrachan, J. (2008). Strategic Planning in Family Business: A Powerful Developmental Tool for the Next Generation. Family Business Review, 21 (3), 239-258.

Miller, D., Steier, L., \& LeBreton-Miller, I. (2003). Lost in time: Intergenerational succession, change and failure in family business. Journal of Business Venturing, 18 (4), 513-531. 
Morris, M.H., Williams, R.O., Allen, J.A., \& Avila, R.A. (1997). Correlates of success in family business transitions. Journal of Business Venturing, 12 (5), 385-401.

Mueller, S. L., \& Thomas, A. S. (2001). Culture and entrepreneurial potential: A nine country study of locus of control and innovativeness. Journal of business venturing, 16 (1), 51-75.

Nonaka, I. (1994). A Dynamic Theory of Organizational Knowledge Creation. Organization Science, 5 (1), 14-37.

Nonaka, I., Toyama, R., \& Konno, N. (2000). SECI, Ba and Leadership: a Unified Model of Dynamic Knowledge Creation. Long Range Planning, 33 (1), 5-34.

Perez-Gonzalez, F. (2006). Inherited control and firm performance. American Economic review, 96, 1559-1588.

Quintaine, E., Casselman, R.M., Reiche, S., \& Nylund, P.A. (2011). Innovation as a knowledge based outcome. Journal of Knowledge Management, 15 (6), 928-947.

Roed, I. (2016). Disentangling the family firms' innovation process. A systematic review, Journal of family business strategy, 7 (3), 185-201.

Rondi, E., De Massis, A., \& Kotlkar, J. (2018). Unlocking innovation potential. A typology of family business innovation postures and the critical role of the family system, Journal of family business strategy, 10 (4), 100236

Saan, R., Enu-Kwesi, F., \& Nyewie, N.F. (2018). Factors influencing succession planning for continuity of family-owned businesses in the wa municipality, Ghana. Universal Journal of management, 6 (5), 165-177.

Sardeshmukh, S.R., \& Corbett, A.C. (2011). The Duality of Internal and External Development of Successors: Opportunity Recognition in Family Firms. Family
Business Review, 24 (2), 111-125.

Sexton, D.L., \& Bowman, N. (1984). Personality inventory for potential entrepreneurs: Evaluation of a modified JPI/ PRF-E test instrument. In: J. Hornaday, F. Tarpley, Jr., J. Timmons, and K. Vesper, eds., Frontiers of Entrepreneurship Research, Wellesley, MA, Babson College.

Sharma, P. (2004). An Overview of the Field of Family Business Studies: Current Status and Directions for the Future. Family Business Review, 17 (1), 1-36.

Sharma, P., Chrisman, J.J., \& Chua, J.H. (2003). Succession Planning as Planned Behavior: Some Empirical Results. Family Business Review, 16 (1), 1-14.

Sharma, P., Chrisman, J.J., \& Gersick, K.E. (2012). 25 Years of Family Business Review: Reflections on the Past and Perspectives for the Future. Family Business Review, 25 (1), 5-15.

Swap, W., Leonard, D., Shields, M., \& Abrams, L. (2001). Using Mentoring and Storytelling to Transfer Knowledge in the Workplace. Journal of Management Information Systems, 18 (1), 95-114.

Szulanski, G. (1996). Exploring internal stickiness. Impediments to the transfer of best practice within the firm. Strategic Management Journal, 17 (Special Winter Issue), 27-43.

Turner, K.L., \& Makhija, M.V. (2006). The role of organizational controls in managing knowledge. Academy of Management Review, 31 (1), 197-217.

Vadnjal, J. \& Ljubotina, P. (2016). Professional trilemma of students with family business experience. Kybernetes: The International Journal of Systems \& Cybernetics, 45 (3), 446-460.

Ward, J. L. (1987). Keeping the Family Business Healthy. San Francisco, US: Jossey-Bass Inc. Publishers. 
Zahra, S. A. (2005). Entrepreneurial risk taking in family firms. Family Business Review, 18 (1), 23-40.

Zehrer, A., \& Leiss, G. (2020). Intergenerational communication barriers and pitfalls of business families in transition - a qualitative action research approach. Corporate communications. An international journal 25 (3), 515.532.

Zelenika, R. (2000). Methodology and technology of scientific and professional work (4th Edition). Rijeka: Economic Faculty in Rijeka. (in Croatian)

Ženko, Z. (2014). Innovating with social responsibility as a source of new opportunities. Pp. 40-51 in: T. Štrukelj, and D. Boršič (Eds.), SEP,ISSN 2232-4593, 4, Maribor: EPF. (in Slovenian)

Ženko, Z., \& Marn, S. (2016). Innovative approach for social changes by young students. In: M. Mulej, A. Hrast \& A. Naterer (Eds.), New social realities from the view of social responsibility, Maribor: IRDO.

Ženko, Z., \& Mulej, M. (2011). Diffusion of innovative behavior with social responsibility. Kybernetes, 40 (9), 12581272. 